\title{
Cloning and Characterization of $\mathrm{Ca}^{2+}$-dependent and $\mathrm{Ca}^{2+}$-independent PKCs Expressed in Aplysia Sensory Cells
}

\author{
Kelly E. Kruger, ${ }^{a}$ Wayne S. Sossin, Todd C. Sacktor, ${ }^{b}$ Peter J. Bergold, ${ }^{b}$ Sven Beushausen, ${ }^{\mathrm{c}}$ and James H. \\ Schwartz \\ Howard Hughes Medical Institute, Center for Neurobiology and Behavior, Columbia University, New York, \\ New York 10032
}

\begin{abstract}
We isolated cDNA clones from an Aplysia sensory-cell library encoding two isoforms of protein kinase C (PKC). Several isozyme-specific regions are conserved in the Aplysia kinases, notably the variable regions $\mathrm{V} 5$ in the $\mathrm{Ca}^{2+}$-dependent PKC (ApI I) and V1 in the $\mathrm{Ca}^{2+}$-independent PKC (ApI II). Neuronal proteins with the properties expected of these two isoforms can be identified with antibodies raised against peptides synthesized from the amino acid sequences deduced from the clones. Sacktor and Schwartz (1990) measured the proportion of kinase activity that can be translocated to membrane in Aplysia sensory neurons and ganglia by stimuli that produce the presynaptic facilitation underlying behavioral sensitization. Much less ApI I and ApI II are translocated, suggesting that still other isoforms of PKC exist in these cells.
\end{abstract}

Protein kinase $\mathrm{C}(\mathrm{PKC})$ has special functions in neurons in addition to its critical role in normal growth and proliferation of many cell types (Nishizuka, 1988). Several neurotransmitters modulate synaptic function by activating this enzyme (Kaczmarek, 1987; Nishizuka, 1988; Rane et al., 1989), and studies in both vertebrates and invertebrates suggest a role for PKC in inducing and maintaining long-term synaptic modifications that are thought to underlie learning and memory (Akers et al., 1986; Farley and Auerbach, 1986; Alkon et al., 1988; Malinow et al., 1988; Olds et al., 1989). In Aplysia neurons, activation of PKC has been implicated in several examples of neuronal modulation (Strong et al., 1987; Conn et al., 1989; Sawada et al., 1989; Taussig et al., 1989; Sacktor and Schwartz, 1990). These include presynaptic facilitation of sensory-to-motor neuron synapses, a cellular process underlying behavioral sensitization or dishabituation (Gingrich and Byrne, 1985; Hochner et al., 1986; Braha et al., 1990). Training that produces sensitization in the animal or application of the facilitatory transmitter 5-HT to isolated ganglia causes translocation of kinase activity from cy-

\footnotetext{
Received Jan. 11, 1991; revised Feb. 27, 1991; accepted Mar. 4, 1991.

We thank Jidong Cai, Alice Elste, and Steven Sturner for excellent technical assistance, Jillayn Lindahl and Christianne Figueroa for typing the manuscript, and Robin Tewes for preparing the figures. W.S.S. is supported by a fellowship from the Medical Research Council of Canada.

Correspondence should be addressed to James H. Schwartz, M.D., Ph.D., Center for Neurobiology and Behavior, 722 West 168th Street, New York, NY 10032.

a Present address: Department of Biological Sciences, Columbia University, New York, NY 10025.

b Present address: Department of Pharmacology, SUNY, Brooklyn, NY 11203.

c Present address: National Institute of Neurological Disorders and Stroke, Laboratory of Neurobiology, Bethesda, MD 20892.
}

Copyright (C) 1991 Society for Neuroscience $0270-6474 / 91 / 112303-11 \$ 03.00 / 0$ tosol to membrane in sensory neurons, an event linked to the activation of the enzyme (Sacktor and Schwartz, 1990).

Several isoforms of PKC have been described (Nishizuka, 1988). All share conserved regions $\left(C_{1}-C_{4}\right)$, which are pieced together with intervening variable regions (V1-V5) specific to each isoform (see Fig. 1). In vertebrates, these enzymes can be placed into two groups, $\mathrm{Ca}^{2+}$-dependent or major $(\alpha, \beta$, and $\gamma)$, and $\mathrm{Ca}^{2+}$-independent or minor $(\delta, \epsilon, \zeta$, and $\eta) . \mathrm{Ca}^{2+}$-dependent PKCs contain a conserved region, $\mathrm{C} 2$, implicated in the $\mathrm{Ca}^{2+}$ dependent translocation of the enzyme to membrane and activation of the kinase (Kaibuchi et al., 1989). $\mathrm{Ca}^{2+}$-independent PKCs lack this region and are not translocated or activated by $\mathrm{Ca}^{2+}$ ions (Akita et al., 1990; Kiley et al., 1990; Schaap and Parker, 1990).

We cloned two types of PKC from a sensory-neuron cDNA library and partially characterized their biochemical properties. One isoform (Apl I) is quite similar to other $\mathrm{Ca}^{2+}$-dependent PKCs and is translocated to neuronal membranes by $\mathrm{Ca}^{2+}$. The other isoform (Apl II) is most similar to $\mathrm{PKC}_{\epsilon}$, which is $\mathrm{Ca}^{2+}$ independent. The translocation of Apl II is not affected by $\mathrm{Ca}^{2+}$ ions, but Apl II can be translocated to phosphatidylserine micelles by phorbol esters. While the reasons for the diversity of kinases are not yet understood, differential affinities for lipid activators, substrate specificity, and susceptibility to inactivation have been offered as explanations for the existence of multiple isoforms of PKC (Sekiguchi et al., 1987; Nishizuka, 1988; Huang et al., 1989; Burns et al., 1990; Huang and Huang, 1990). Characterization of PKCs in Aplysia neurons with known physiological actions can lead to an understanding of how specific isoforms function in synaptic plasticity.

\section{Materials and Methods}

Aplysia californica weighing 100-200 gm were obtained from the Howard Hughes Mariculture Facility at the Woods Hole Oceanographic Institution (Woods Hole, MA) or from Sea Life Supply (Sand City, CA). All chemicals are from Sigma (St. Louis, MO) unless otherwise stated.

Translocation of PKC. Pleural-pedal ganglia, isolated from animals by dissection, were homogenized in $50 \mathrm{~mm}$ Tris- $\mathrm{HCl}(\mathrm{pH} 7.5), 10 \mathrm{~mm}$ $\mathrm{MgCl}_{2}, 0.5$ mм EGTA (or $1 \mathrm{~mm}$ EDTA), $0.1 \mathrm{~mm}$ phenylmethylsulfonylfluoride, $5 \mathrm{~mm} 2$-mercaptoethanol, aprotonin $(50 \mu \mathrm{g} / \mathrm{ml})$, benzamidine $(5 \mathrm{mM})$, and leupeptin $(0.1 \mathrm{mM})$, then centrifuged for $1 \mathrm{~min}$ at $1000 \times$ $g$ to remove debris (unhomogenizcd cells and sheath). Inclusion of $\mathrm{MgCl}_{2}$ at a concentration physiological for Aplysia in the homogenization buffer increases the proportion of cytosolic PKC (Sacktor and Schwartz, 1990). The supernatant was incubated for $20 \mathrm{~min}$ at $20^{\circ} \mathrm{C}$ in the presence or absence of $200 \mathrm{~nm}$ phorbol dibutyrate (PDBu), and then centrifuged at $100,000 \times g$ to separate cytosol and membrane fractions. In some experiments, supernatants from extracts not incubated in PDBu were then incubated for $20 \mathrm{~min}$ at $20^{\circ} \mathrm{C}$ with $150 \mathrm{mg} / \mathrm{ml}$ phosphatidylserine (Avanti Polar Lipids, Alabaster, AL) in the presence or absence of PDBu. 


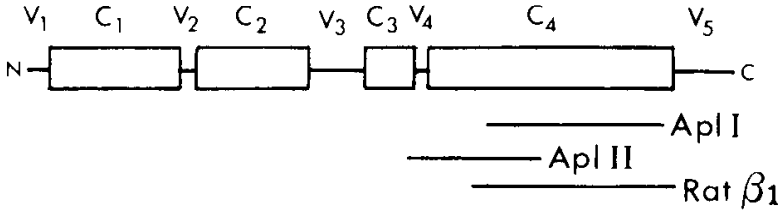

Figure 1. Diagram of a $\mathrm{Ca}^{2+}$-dependent isoform of $\mathrm{PKC}$ showing the regions encoded by the cDNA probes used. $C_{1}-C_{4}$ are conserved domains, and $V_{1}-V_{5}$ refer to variable regions that differ among isoforms. The $C_{2}$ domain is absent in the $\mathrm{Ca}^{2+}$-independent enzymes $\delta, \epsilon, \zeta$, and $\eta$. The Apl I clone shown, the longest cDNA obtained in the screening of the pleural sensory-cell cDNA library, was used in Sl protection assays (see Fig. 7) and is shown in the figure beneath the diagram of the major isoforms of PKC. Apl II is the only cDNA for the $\mathrm{Ca}^{2+}$-independent Aplysia PKC isolated from the library and was also used in the Sl protection assays as well as for in situ hybridization (see Fig. 8). The rat $\beta \mathrm{I}$ PKC cDNA was used to screen the library at low stringency.

To test the effect of $\mathrm{Ca}^{2+}$, extracts of pleural-pedal ganglia were diluted into EGTA-Ca ${ }^{2+}$ buffers (Eliot et al., 1989) with $20 \mathrm{mM} \mathrm{HEPES} \mathrm{(pH,}$ 7.6) and $100 \mu \mathrm{M}$ leupeptin in the presence or absence of PDBu. Isolated ganglia were exposed to 5-HT and PDBu as described by Sacktor and Schwartz (1990) but with $1 \mu \mathrm{M}$ PDBu to ensure accessibility of the drug because the connective tissue sheath was not completely removed.

Screening libraries. A pleural sensory-cell library (the gift of Michael Knapp, Philip Goelet, and Vincent Castellucci) containing $3 \times 10^{5}$ phage was screened at low stringency for $16 \mathrm{hr}$ at $42^{\circ} \mathrm{C}$ in a standard hybridization mixture of $30 \%$ formamide, $5 \times$ SSC $(1 \times$ SSC: $0.15 \mathrm{M} \mathrm{NaCl}$ $0.015 \mathrm{~m} \mathrm{Na}$ citrate), $10 \times$ Denhardt's solution, $1 \%$ SDS, and $20 \mathrm{~mm} \mathrm{Na}$ phosphate $(\mathrm{pH}, 7.0)$ with $250 \mu \mathrm{g} / \mathrm{ml}$ of denatured salmon sperm DNA and then washed at $55^{\circ} \mathrm{C}$ in $2 \times$ SSC containing $1 \%$ SDS. We screened a randomly primed cDNA library of the total Aplysia nervous system at high stringency as described by Beushausen et al. (1988).

Anchored PCR cloning of the $5^{\prime}$ end of Apl II. Randomly primed Aplysia nervous tissue cDNA, tailed at the 5 ' end with oligo-G by terminal deoxynucleotidyl transferase (Bethesda Research Laboratories, Gaithersburg, MD), was amplified with a $3^{\prime}$ primer (CACATCATCAAACGGAATCGTGC) derived from a sequence approximately 100 base pairs (bp) from the end of the longest Apl II cDNA and a $5^{\prime}$ primer consisting of polyC. The product was amplified again with an internal $3^{\prime}$ primer (GGAATTCCGTCTTCAACGGTTCGGTGAA) and a $5^{\prime}$ polyC primer with EcoRI sites at their ends. The amplified DNA was cut with EcoRI and ligated into $\lambda$-Zap II (Stratagene, La Jolla, CA).

DNA sequencing. cDNA clones were subcloned into Bluescript phagemids (Stratagene) for sequencing by the dideoxy chain-termination method of Sanger et al. (1977) with reagents and protocols from United States Biochemical Corporation (Cleveland, OH) using ${ }^{35} \mathrm{~S}-\mathrm{dATP}$ (Amersham, Arlington Heights, IL) as label. Clones were sequenced from their ends using the primers provided by Stratagene. Internal regions were sequenced with primers, 17 nucleotides in length, synthesized by the Protein Chemistry Core Facility at Columbia University using previously determined sequences. All sequencing was done on both strands.

Expression of Apl I and Apl II. Northern blotting, SI nuclease protection experiments, and in situ hybridization were done as described by Beushausen et al. (1988).

Production of Apl I and Apl II antibodies. Peptides derived from the C-terminal sequence of Apl I ( $\mathrm{NH}_{2}$-CSYVNPEFVVTV) and Apl II ( $\mathrm{NH}_{2-}$ CSFANPDYGKLEMEASGOAH) were synthesized by Peninsula Laboratories (Belmont, $\mathrm{CA}$ ). Cysteine residues were added to the $\mathrm{N}$-termini of the peptides for cross-linking to maleimide-activated bovine serum albumin (BSA) using the protocol provided by the manufacturer (Pierce Chemical Co., Rockford, IL). The cross-linked peptides $(0.5 \mathrm{mg})$ were emulsified in an equal volume of RAS adjuvent (RIBI, Hamilton, MO) for injection into Hare Marland rabbits four times at monthly intervals. Antisera were purified with a column made by linking the synthesized peptides to Sulfolink beads using instructions provided by Pierce. Antisera were diluted four times in normal phosphate-buffered saline (PBS; $0.15 \mathrm{M} \mathrm{NaCl}, \mathrm{pH} 7.0)$ and applied to the affinity column $(10 \mathrm{ml} / \mathrm{hr})$ at $4^{\circ} \mathrm{C}$, which were then washed with three column volumes each of PBS, PBS with $0.65 \mathrm{M} \mathrm{NaCl}$, and then PBS again, and eluted with either 0.1 м glycine (pH 2.3) or $0.1 \mathrm{~m}$ triethylamine (pH 11.5). Fractions (1 ml) were collected and neutralized rapidly with either $0.1 \mathrm{ml}$ of $1 \mathrm{M}$ Tris base ( $\mathrm{pH} \mathrm{9.5)} \mathrm{or} 0.1 \mathrm{ml}$ of $1 \mathrm{M}$ triethanolamine $(\mathrm{pH} 6.0)$.
Western blotting. Protein samples were electrophoresed on 8-10\% SDS-polyacrylamide gels (Laemmli, 1970) and blotted onto nitrocellulose filters (BioRad, Rockville Center, NY). The filters were then blocked with $5 \%$ BSA in TSN (10 mM Tris-HCl, pH 7.4, $150 \mathrm{~mm} \mathrm{NaCl}$, $0.05-0.2 \% \mathrm{NP}-40$ ) for $30 \mathrm{~min}$ at room temperature, and then treated with either a 1:1000 dilution of affinity-purified Apl II antiserum, a 1:1000 dilution of anti-rat $\beta I$ (the gift of Drs. K. Ase and Y. Nishizuka, Kobe University School of Medicine; Ase et al., 1988), or a 1:500 dilution of affinity-purified Apl I antiserum in TSN. Because the Apl I and Apl II proteins are well separated by gel electrophoresis, we often used the two antisera together on the same blot. Blots were washed six times each for 5 min with TSN and then incubated in TSN with a 1:5000 dilution of secondary antibody linked to alkaline phosphatase and developed according to the manufacturer's instructions (Promega, Madison, MI). Results were normalized to total membrane protein as measured by a modification of the Bradford assay (Sacktor and Schwartz, $1990)$ and were in the linear range ( $20 \mu \mathrm{g}$ protein) for detection by the phosphatase reaction. For the experiments presented in Table 1, two or three pairs of pleural-pedal ganglia were needed for each determination. Proteins on Western blots were quantitated with a scanning densitometer (model GS300, Hoefer, San Francisco, CA).

\section{Results}

Two isoforms of PKC cloned from the Aplysia nervous system We obtained four hybridizing cDNAs by screening $3.6 \times 10^{5}$ phage from a pleural sensory cell cDNA library at low stringency with a rat $\beta-1$ PKC cDNA probe (the gift of G. M. Housey and I. B. Weinstein, Columbia University; Housey et al., 1987). This heterologous probe encodes $\mathrm{C} 4$, a conserved segment in the catalytic domain (Fig. 1). Hybridization analyses and sequencing of the Aplysia cDNAs indicated that we had isolated two types of clones, Apl I (three of the clones) and Apl II.

\section{The sequence of Apl I PKC}

To obtain the complete cloning sequence of Apl I, we screened a randomly primed cDNA library of the total nervous system at high stringency with the longest of the three Apl I cDNAs (Fig. 1). The coding sequence of Apl I cDNA and its deduced amino acid sequence are shown in Figure 2.

Apl I is similar to all of the $\mathrm{Ca}^{2+}$-dependent isoforms described (65-73\% amino acid identity; Parker et al., 1986; Kikkawa et al., 1987; Fig. 3); it is closest to the PKC of Drosophila brain (Rosenthal et al., 1987). The nucleotide sequence around the codon putatively identified as the initiator for Apl I fulfills some of the criteria for a eukaryotic initiator methionine residue (Kozak, 1981). The five variable (V1-5) and four constant (C1-4) regions align with those of the vertebrate $\mathrm{Ca}^{2+}$-dependent kinases. With the exception of $\mathrm{V} 1$, the length of each region is also well conserved.

All but one of the variable regions in Apl I are not characteristic of any vertebrate homolog. The only residues conserved in the variable regions (V1-4) are those that are also conserved between the $\alpha-, \beta$-, and $\gamma$-isoforms. The exception is in V5, which contains several amino acids that are identical to the mammalian $\beta$-1 kinase but not to any of the other isoforms (asterisks in Fig. 3). Most of these amino acids are also conserved in the Drosophila $\mathrm{Ca}^{2+}$-dependent PKCs, though the published dPKC53G (br) sequence is frame-shifted at bp 2758 just before the strong similarity to $\beta$ I (Rosenthal et al., 1987). Glu-611, Ser-606, and Asp-604 are also conserved in the yeast enzyme (Levin et al., 1990).

\section{The sequence of Apl II PKC}

The sequence of Apl II is shown in Figure 4. This isoform is most similar to mammalian PKC $\epsilon$ and the $98 \mathrm{~F}$ kinase of Dro- 


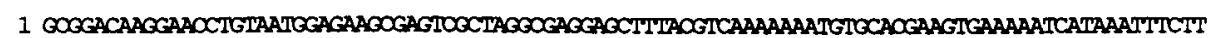
$\begin{array}{lllllllllllllllllllllllllll}M & E & K & R & V & A & R & R & G & A & L & R & Q & K & N & V & H & E & V & K & N & H & K & F & L\end{array}$

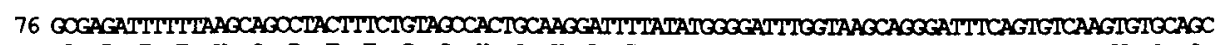
$\begin{array}{lllllllllllllllllllllllllllllllll}A & R & F & F & K & Q & P & T & F & C & S & H & C & K & D & F & I & W & G & F & G & K & Q & G & F & Q & C & Q & V & C & S\end{array}$

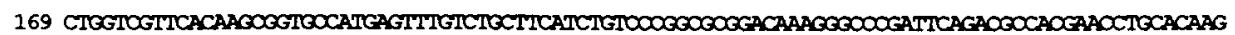
$\begin{array}{lllllllllllllllllllllllllllllll}\text { L } & V & V & H & K & R & C & H & E & F & V & C & F & I & C & P & G & A & D & K & G & P & D & S & D & A & T & N & L & H & K\end{array}$

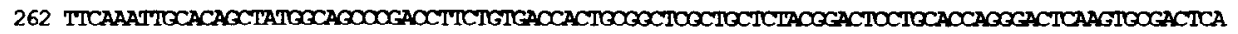
$\begin{array}{llllllllllllllllllllllllllllllllll} & F & K & L & H & S & Y & G & S & P & T & F & C & D & H & C & G & S & L & L & Y & G & L & L & H & Q & G & L & K & C & D & S\end{array}$

355 TGTGACATGAAOGIACACAACOOCIGOCAGAAGAAOGTCOOOCTOCTGTGTOOCACOGAOCACAOCGACAGOOGTGCACGTATPCTCATCAAA $\begin{array}{llllllllllllllllllllllllllllllllll}C & D & M & N & V & H & K & R & C & E & K & N & V & P & L & L & C & G & T & D & H & T & E & R & R & G & R & I & I & I & K\end{array}$

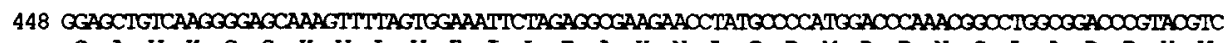
$\begin{array}{llllllllllllllllllllllllllllllll}G & A & V & K & G & S & K & V & I & V & E & I & L & E & A & K & N & L & C & P & M & D & P & N & G & L & A & D & P & Y & V\end{array}$

541 AAAGIGAACTCATOOCTTACGAOGCOCACAACCTAAACCTCAAGACGAAACTATCAAACOCICTCTCAACOCOGTCTGCAADGACAQCTTC

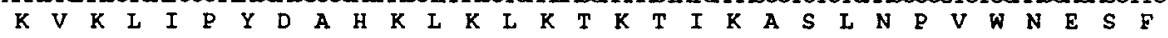

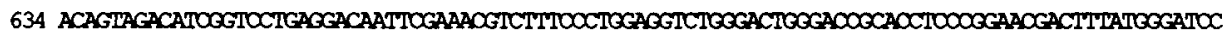
$\begin{array}{llllllllllllllllllllllllllllllll}T & V & D & I & G & P & E & D & N & S & K & R & L & S & L & E & V & W & D & W & D & R & T & S & R & N & D & F & M & G & S\end{array}$

727 CTGTOCTOOOCATCTCAGAGTTGATCAAGICTOCTGTGCAAGCCTGGTTMAACCTCCTCAACCAGGAGGAGGAGAGTTCTATGOCGTOOCT $\begin{array}{llllllllllllllllllllllllllllllllll}L & S & E & G & I & S & E & L & I & K & S & P & V & E & G & W & F & K & L & L & N & Q & E & E & G & E & F & Y & G & V & P\end{array}$

820 GTCACOGATCACATCACAGAGAOCATTCAGGAGATCAAGAOCAAGATGCACOGGTCAAGCATCACCAGTGAGAAGCOCTACOOGGACOOOCAC $\begin{array}{lllllllllllllllllllllllllllllllll}V & T & D & D & I & T & E & S & I & Q & E & I & K & S & K & M & H & R & S & S & I & S & S & E & K & R & Y & P & E & P & D\end{array}$

913 AACGITCAAAACATGACCAAACAAGACATTGTOOGTOOCAOCGACTTCAACTTCCTCACTGTOCTOGCCAAAGGAAGTTTGGAAAGGTOGTG $\begin{array}{llllllllllllllllllllllllllllllll}K & V & Q & N & M & S & K & Q & D & I & V & R & A & S & D & F & N & F & L & T & V & L & G & K & G & S & F & G & K & V & V\end{array}$

1006 TIGOCTGAGAGAAGGOCACGGATGAGCTGTATGCAATIAAGATCTIGAAGAAGGAOGTGATAATICAGGAOGACGATGTAGAGTGIACCATG

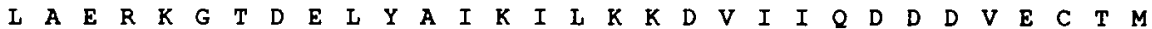

1099 ATAGAGAAGAGAGTOCTAOOOCTCOCTGATAAAOCTOCATIOCTGGTOCAACTGCACTOCTGCTIOCACACCATGCACOOCCTGTACTITGTC

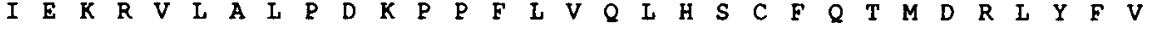

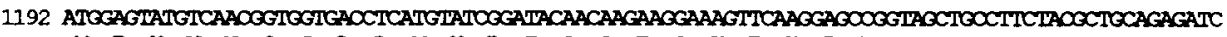

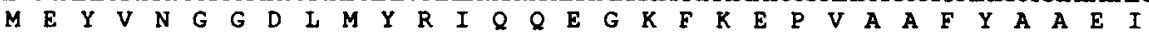

1285 QCTATTCOOCTTTTYYCCTOCATACTCAAGCATTGTATACACAGATCTCAACCTACATAATGTGATGTTAGACOCTGAGOGTCATATCAAA $\begin{array}{lllllllllllllllllllllllllllllllllll}\text { A } & I & G & L & F & Y & L & H & T & Q & G & I & V & Y & R & D & L & K & L & D & N & V & M & L & D & A & E & G & H & I & K\end{array}$

1378 ATPACAGAYTITGOCATGIGCAAACAGAACATAATGOOCACAAACTAOOOGCACTITCTGIGGCACOCOOCACIACATOCOOOCAGAGATT $\begin{array}{lllllllllllllllllllllllllllllllll}I & A & D & F & G & M & C & K & E & N & I & M & G & D & K & T & T & R & T & F & C & G & T & P & D & Y & I & A & P & E & I\end{array}$

1471 GITITIATAOCAGOOGTAOGGOOGATCIGTGGACTGGTGOCOCTATGCAGTGITGCTGIAOGAGATGCTGOCIGCACAGOCICCTIITGATGGT

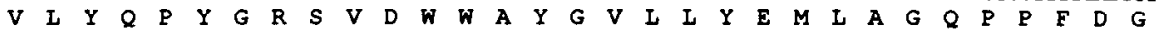

1564 GAGGATGAGAGCAGCTGTTCACCTOCATAACOCACCACAACGTGIOCTACOOCAAGOCTCIGICIOOCCACOOOGICICACTCIGCAAACOG

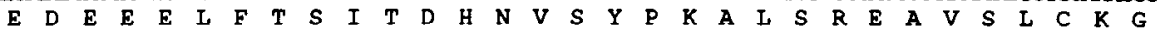

1657 TIATTGAOCAACACTOCAOCCAAACACTGOGCTGOGCOOOCAATGGTGAGOOOCACATCAAGGACOSOCOCTICTTCAGCOOCATOCAGTGG

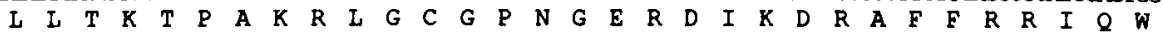

1750 GAGACGATAGAACTGAGGCAGGIOCACOOSOCCTACAAAOCTAGGAITAAATOOOOCAAAGATGICAGIAACTTTGACOCAGAGTTCAOGTCT $\begin{array}{lllllllllllllllllllllllllllllllll}E & R & I & E & L & R & E & V & O & P & P & Y & K & P & R & I & K & S & R & K & D & V & S & N & F & D & R & E & F & T & S\end{array}$

1843 GAACCTCOCAACGTGACOOOCACOGACAAACTGTTCATCATGAACCTOGACAGTGIGAATTCTOOOOCTICTCATATGTCAACOCAGAGTTT

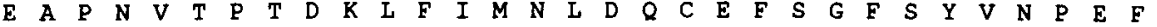

1936 GTOGTCACTGTTTACAGTTGAGAAAGACAAAGGTGTGCTCICAGTTIAGCTGPAGAG

$\mathrm{V} V \mathrm{~T} V$
Figure 2. Nucleic acid sequence of Apl I cDNA with the deduced amino acid sequence shown in the single-letter code. We sequenced overlapping cDNA clones obtained by screening the pleural sensory-cell cDNA library and the randomly primed library. A 1.5-kilobase $(\mathrm{kb})$ cDNA provided the sequence encoding the C-terminal end of Apl I, and the other, a 1.6-kb cDNA, extended into $\mathrm{C} 1$. To complete the sequence of Apl I, the randomly primed cDNA library was screened with a probe from the $5^{\prime}$ end of the $1.6-\mathrm{kb}$ clone to obtain two other cDNA clones that extend to the initiating methionine codon. sophila (65\% identity; Ohno et al., 1988; Ono et al., 1988; Schaeffer et al., 1989). The absence of a C2 region is an indication that Apl II is $\mathrm{Ca}^{2+}$-independent. Unlike Apl I, Apl II contains sequences in variable regions throughout the molecule that are highly conserved in all $\epsilon$-isoforms thus far cloned, but not present in other PKCs (asterisks in Fig. 5).

Of possible functional interest are the five domains of the Apl II sequence bracketed in Figure 5. The first two are in V1, a region that is quite long in $\mathrm{Ca}^{+}$-independent kinases previously described, but whose function is not yet known. Probably because of a frame shift upstream, Schaeffer et al. (1989) placed these sequences in the $5^{\prime}$ untranslated region of the Drosophila $98 \mathrm{~F}$ kinase. This error would lead to the misidentification of a downstream methionine codon as initiator. Consequently, they did not notice that the $\mathrm{V} 1$ region is conserved throughout phylogeny. The third domain, the pseudosubstrate sequence and the region immediately $\mathrm{C}$-terminal to it, is also peculiar to $\mathrm{\epsilon}$-isoforms. The fourth, which is an insert in $\mathrm{Cl}$, is similar in both the $\delta$ - and $\epsilon$-isoforms. Finally, there are sequences in the $\mathrm{C} 4$ region that are common to all PKCes.

\section{Expression of PKC}

Northern blot analysis demonstrates that both Apl I and Apl II are expressed in nervous tissue as transcripts much longer than 5 kilobases (kb; Fig. 6). A large size is not unusual for Aplysia transcripts; for example, both regulatory and catalytic subunits of the cAMP-dependent protein kinase are also encoded by large transcripts (Beushausen et al., 1988; Bergold et al., 1990). 


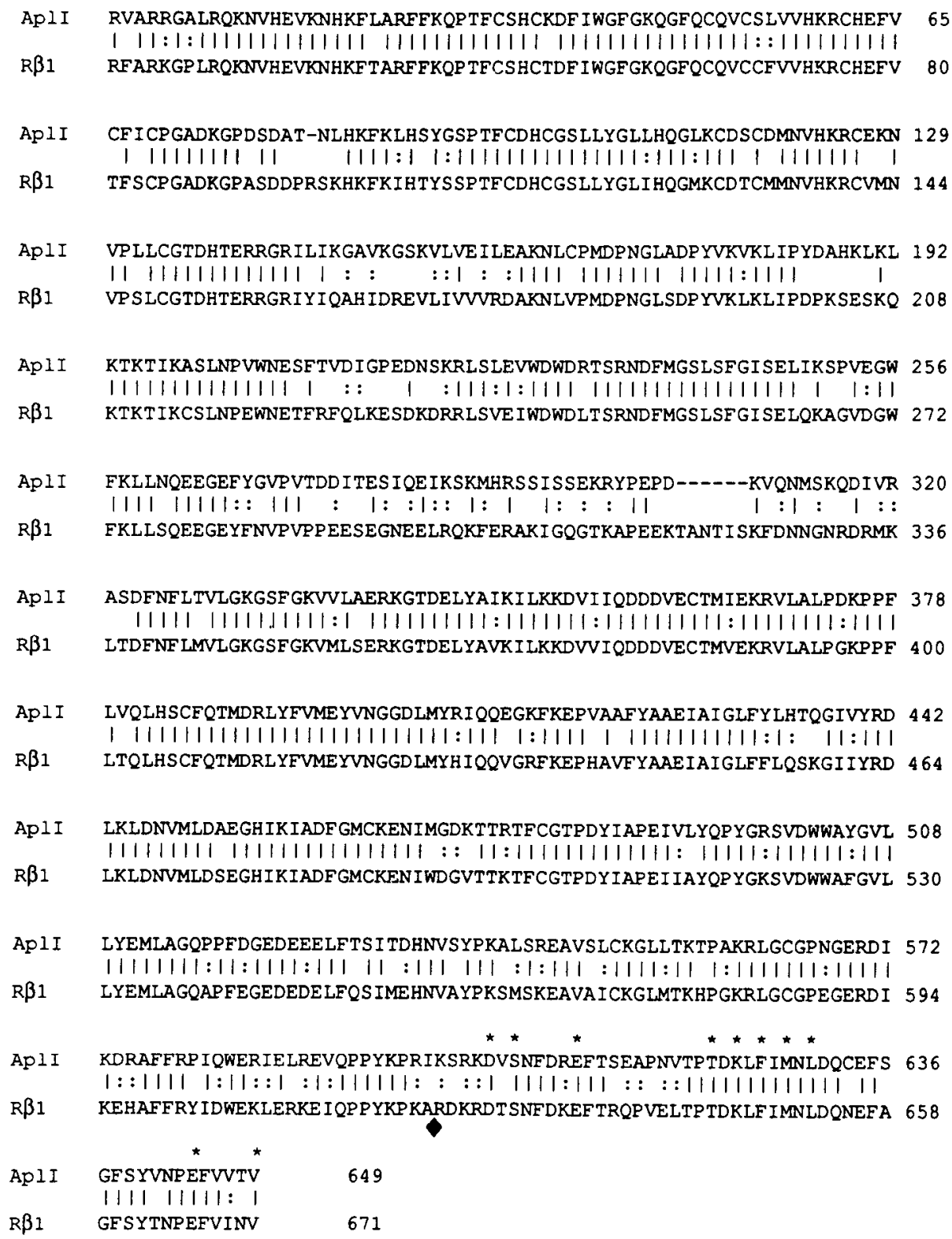

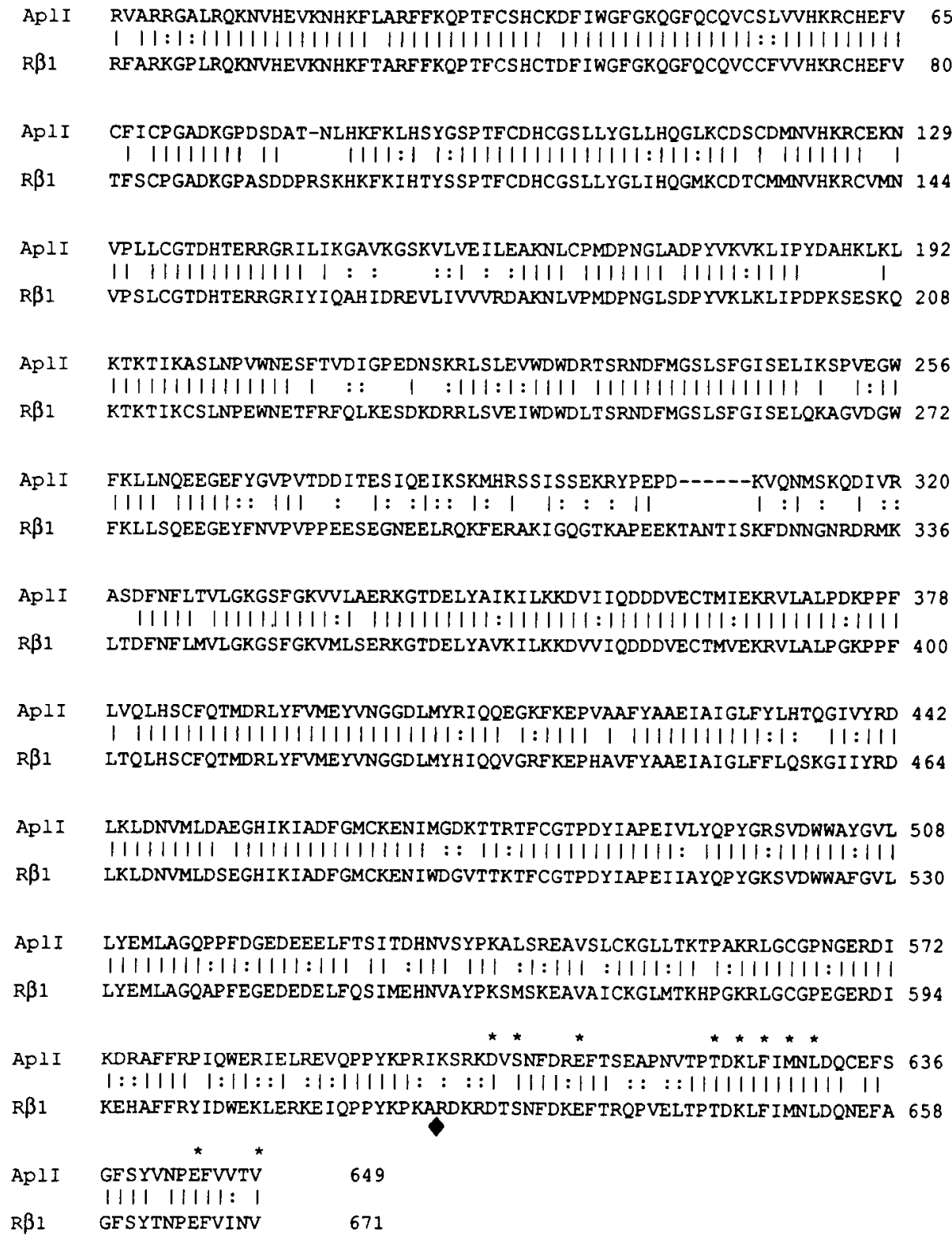

Figure 3. Comparison of Apl I with rat $\beta$ I PKC. Output by the Bestfit algorithm (Devereaux et al., 1984). |, identity; :, a conservative substitution. Gaps are represented by -. Asterisks above the sequence indicate residues that are identical between Apl I and $\beta \mathrm{I}$ PKCs but that are not present in the mammalian $\beta \mathrm{II}$, the $\alpha-$, or the $\gamma$-isoforms. The diamond points to the splice junction in the mammalian enzyme (Coussens et al., 1987).
Amounts of the Aplysia PKC transcripts were assessed in nervous tissue and in several other organs by nuclease Sl protection experiments (Fig. 7). In RNA from nervous tissue, Apl II is approximately three times more abundant than Apl I (Fig. $7 A$ ). To survey the expression of the two isoforms in other tissues (Fig. $7 B$ ), we hybridized labeled antisense probes to total RNA isolated from buccal muscle (Fig. $7 B$, lanes 5,6 ), gut (lanes 7 , 8 ), salivary gland (lanes 9,10 ), and ovotestis (lanes 11,12), in addition to nervous tissue (lanes 1,3). While Apl I RNA is much more plentiful in the nervous system, longer exposure of the autoradiograms shows that small amounts are also present in the other tissues. Apl II mRNA, the more abundant transcript in nervous tissue, is present in substantial amounts in ovotestis and gut, but is not plentiful in the other tissues.

The Apl I transcript is probably alternatively spliced. Longer exposure of the autoradiograph also reveals a protected fragment of the Apl I mRNA that is much more abundant in gut and ovotestis than in nervous tissue (arrows in Fig. $7 B$ ). The predicted splice junction corresponds to the splice site reported for the mammalian $\beta \mathrm{I} / \beta \mathrm{II} \mathrm{PKC}$ gene (diamond in Fig. 3). Alternative splicing at this site results in kinase proteins that differ only in their C-terminal 50 amino acids (Coussens et al., 1987).

\section{Expression of Apl II in identified neurons}

In situ hybridization demonstrates that Apl II is expressed in all nerve cells, including sensory neurons (Fig. 8) and bag cells (data not shown). Little hybridization is seen in glia or the connective tissue sheath. Hybridization to the antisense RNA is predominant in the cytoplasm of the sensory neurons and bag cells, but can also be seen in their processes. A similar distribution of hybridization was seen in sensory neurons with the catalytic subunits of the Aplysia cAMP-dependent protein kinase (Beushausen et al., 1988). The proximal process of Aplysia neurons may actually be considered part of the cell body because it contains ribosomes and other somatic organelles at considerable distances from the perikaryon (e.g., see Schwartz et al., 1986). 


\begin{abstract}
1 GTGCTAAAATTCGTATTACAACTTCCGTGATATTTTTTGCTGTGATATTCTCAGTTCAACTGGATTAAATTTGATCGCCAGGCCTCTAAATGC 94 TACCCCGGACGGCAGGATTTGGCTGAGTTATCCCCGATCCTCTGCTGAGGCCTCTGAGCGGGCTTCAATGTCGCGGAGGGCCAAAATGGTCTT $M$ S R R A K M V
\end{abstract}

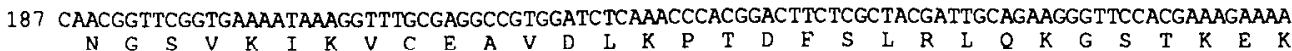
280 AGCCTCGCAGATGATTGAGCCCTACGTGAATATTGATGTGGATGAAGTGTACATAGCTAAGACCACTACGAAGCCCAAAAGTGTTAAACCACA

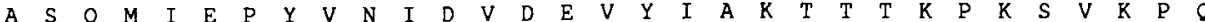
373 GTGGGTTTGGAACGAGGATTTCACGTCGGAAGTTCACAATGGACAGAATGTGAATCTAACGGTGTTTCATGACGCCGCAATTCCACCCGACGA

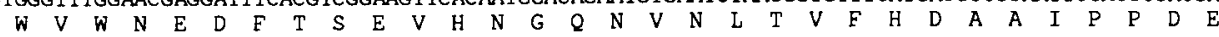

466 GTTCGTTGCCAACTGCACGATTCCG TTTGATGATGTGAAAGGAAAATCTGACTTTTGGATCGATTTGGAACCAAA'IGGAAAAC'IGCACG'IG' $\begin{array}{lllllllllllllllllllllllllllllllll}F & V & A & N & C & T & I & P & F & D & D & V & K & G & K & S & D & F & W & I & D & L & E & P & N & G & K & L & H & V & V\end{array}$ 559 TATCGAGCTGTGTGGCTCCGCAACGGAAGCTGCGGAGTCCACACCAAAGGAGAAAGTGTTCAAAGAAAAGGAAGGTATGCTCAACCGGCGGCG $\begin{array}{lllllllllllllllllllllllllllllllll}I & E & L & C & G & S & A & T & E & A & A & E & S & T & P & K & E & K & V & F & K & E & K & E & G & M & L & N & R & R & R\end{array}$ 652 TGGGGCCATGCGTCGTCGGGTTCATCAGGTCAACGGCCACAAGTTCATGGCAATGTTCTTCAGACAACCCACATTCTGCTCGCTGTGCCGGGA $\begin{array}{lllllllllllllllllllllllllllllllll}G & A & M & R & R & R & V & H & Q & V & N & G & H & K & F & M & A & M & F & F & R & Q & P & T & F & C & S & L & C & R & D\end{array}$

745 CTTTATCTGGGGTCTTGGCAAGCAAGGGTACCAGTGCCAAGTGTGTACATGCGTGGTTCACAAGCGATGTCACCAGCATATAGTCACCAAATG $\begin{array}{lllllllllllllllllllllllllllllll} & I & W & G & L & G & K & O & G & Y & 0 & C & 0 & V & C & T & C & V & V & H & K & R & C & H & Q & H & I & V & T & K & C\end{array}$ 838 TCCCGGTTCCCGGGATGTAGCTAATGATGAGGTGACGGGCAAGCGGTTCAACATCAACGTACCACACAGATTCAACGTACACAACTATAGGCG $\begin{array}{lllllllllllllllllllllllllllllllllll}\mathrm{P} & G & S & R & D & V & A & N & D & E & V & T & G & K & R & F & N & I & N & V & P & H & R & F & N & V & H & N & Y & R & R\end{array}$ 931 GCCAACCTTCTGTGATCATTGTGGCTCTCTGCTCTACGGGCTGGTGAGACAGGGACTGCAGTGCGATGTGTGCAAGATGAACATTCACAAGAG $\begin{array}{llllllllllllllllllllllllllllllll}P & T & F & C & D & H & C & G & S & L & L & Y & G & L & V & R & Q & G & L & Q & C & D & V & C & K & M & N & I & H & K & R\end{array}$

1024 ATGCCAGAAGAATGTGGCGAACAACTGCGGCACGAACACCCGAGACATGGCCCAGATCTTACAGGAGATGGGCATATCAGGGGACAAACTTAG $\begin{array}{lllllllllllllllllllllllllllllllllll}C & 0 & K & N & V & A & N & N & C & G & T & N & T & R & D & M & A & Q & I & L & Q & E & M & G & I & S & G & D & K & L & R\end{array}$

1117 ACCCAAGACCAAAAAGCTGTCAATAAGTGAGTCCCATGAGTCCCCAAATAAAAGTTCCCCCATGCATGAGAGATCTTTATCATCCCCTATACC $\begin{array}{lllllllllllllllllllllllllllllllllll}\mathrm{P} & K & \mathrm{~T} & \mathrm{~K} & \mathrm{~K} & \mathrm{~L} & \mathrm{~S} & \mathrm{I} & \mathrm{S} & \mathrm{E} & \mathrm{S} & \mathrm{H} & \mathrm{E} & \mathrm{S} & \mathrm{P} & \mathrm{N} & \mathrm{K} & \mathrm{S} & \mathrm{S} & \mathrm{P} & \mathrm{M} & \mathrm{H} & \mathrm{E} & \mathrm{R} & \mathrm{S} & \mathrm{L} & \mathrm{S} & \mathrm{S} & \mathrm{P} & \mathrm{I} & \mathrm{P}\end{array}$

1210 TGTGATCCAAGACTCTGATGAGGCACAACCCGGCGAGATGGGGCTGCCCAGCGACAGTCTACCGGTCAATGCTAGCAATGACCATCAGGGTTC $\begin{array}{lllllllllllllllllllllllllllllllll}V & I & Q & D & S & D & E & A & Q & P & G & E & M & G & L & P & S & D & S & I & P & V & N & A & S & N & E & H & Q & G & S\end{array}$ 1303 CCGTACACGGAGCCCCTCCAGTGACCGCTCGCGCTCCCACCACAGTCGCATCAGCTTGCACGACTTCAATTTTATCAAAGTCCTGGGCAAAGG

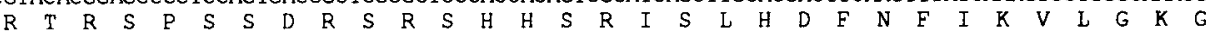

1396 CAGTTTTGGAAAAGTGATGTTAGCAGAGAAGAAAGGGACAGATGAAGTATATGCTATAAAAGTTTTGAAAAAGGATGTGATTATACAAGATGA $\begin{array}{lllllllllllllllllllllllllllllllll}S & F & G & K & V & M & L & A & E & K & K & G & T & D & E & V & Y & A & I & K & V & L & K & K & D & V & I & I & Q & D & D\end{array}$

1489 TGATGTGGAATGTACAATGACAGAAAAAAGAATATTAGCATTGTCAGCCAAACATCCTTTTCTTACTGCACTTCACTCATCTTTCCAGACGAA $\begin{array}{llllllllllllllllllllllllllllllllll}D & V & E & C & T & M & T & E & K & R & I & L & A & L & S & A & K & H & P & F & L & T & A & L & H & S & S & F & Q & T & K\end{array}$

1582 GCAACGATTGTTCTTTGTCATGGAGTATGTAAATGGAGGAGATCTCATGTTCCAAATTCAACGGGCTCGCAAGTTTGATGAGCCTCGGCCACG

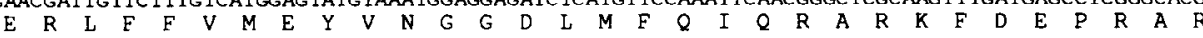

1675 GTTTTATGCGGCTGAGGTGACATTAGCTCTTATGTTTCTGCATAGGCACGGTATTATATACAGAGATCTGAAATTAGACAACATATTGCTGGA $\begin{array}{llllllllllllllllllllllllllllllllll}\text { F } & Y & A & A & E & V & T & L & A & L & M & F & L & H & R & H & G & I & I & Y & R & D & L & K & L & D & N & I & L & L & D\end{array}$

1768 TGCTGAAGGACATTGCAAGATTGCTGACTTTGGAATGTGCAAAGAAGGCATGACAGAGAACAAATTAACGCAGACATTCTGTGGCACTCCGGA

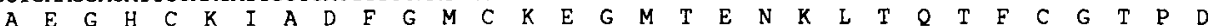

1861 CTACATTGCACCGGAGATCCTGCAAGAACTCAAGTATGATGCCAGTGTGGACTGGTGGGCACTGGGCGTCCTCATGTATGAGATGATGGCAGG $\begin{array}{llllllllllllllllllllllllllllllllllll}Y & I & A & P & E & I & L & Q & E & L & K & Y & D & A & S & V & D & W & W & A & L & G & V & L & M & Y & E & M & M & A & G\end{array}$

1954 ACAGCCGCCGTTTGAGGCGGACAACGAAGACGACTTGTTTGAGTCTATTTTGCATGACGATGTCCTTTACCCTGTCTGGCTCAGCAAAGAGGC $\begin{array}{llllllllllllllllllllllllllllllll}Q & P & P & F & E & A & D & N & E & D & D & L & F & E & S & I & L & H & D & D & V & L & Y & P & V & W & L & S & K & E & A\end{array}$

2047 AG'L'I'L'ATACTCAAGGGGTTTATGACTAAAAACCCTGCCAAGCGACTCGGCTGTGTTACTACCCAAGGGTGCGAAAAAGCAATCCTTGTTCA $\begin{array}{lllllllllllllllllllllllllllllllllll}V & S & I & L & K & G & F & M & T & K & N & P & A & K & R & L & G & C & V & T & T & Q & G & C & E & K & A & I & L & V & H\end{array}$

2140 TCCATTTTTCCATGAAAAAATTGATTGGGAAGCTTTGGAACAACGCAAAGTGAAGCCGCCATTCAAGCCAAAAATAAAAAACAAAACGGATGC $\begin{array}{lllllllllllllllllllllllllllllll}\mathrm{P} & \mathrm{F} & \mathrm{F} & \mathrm{H} & \mathrm{E} & \mathrm{K} & \mathrm{I} & \mathrm{D} & \boldsymbol{W} & \mathrm{E} & \mathrm{A} & \mathrm{L} & \mathrm{E} & \mathrm{Q} & \mathrm{R} & \mathrm{K} & \mathrm{V} & \mathrm{K} & \mathrm{P} & \mathrm{P} & \mathrm{F} & \mathrm{K} & \mathrm{P} & \mathrm{K} & \mathrm{I} & \mathrm{K} & \mathrm{N} & \mathrm{K} & \mathrm{T} & \mathrm{D} & \mathrm{A}\end{array}$

2233 CAATAACTTCGACCGGGACTTCACGTCAGAGGACCCTGTCCTGACGCCGGTGGATCCGGCCGTGATAAAGACCATAAACCAAGAAGAGTTCCG

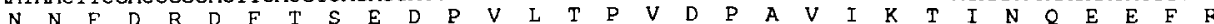

2326 CGGCTTCTCGTTTGCCAATCCAGACTACGGCAAGTTAGAAATGGAGGCAAGTGGCCAGGCGCACTGACCAGCCATCCGGGCAGGGGACTGCCC $G \begin{array}{llllllllllllllllllllllllll} & F & S & F & A & N & P & D & Y & G & K & L & E & M & E & A & S & G & Q & A & H & -\end{array}$

2419 GCCAAGCTCATTCTCCGGACCATTCACTTCAAATGATGATGGTGGCTGTGTTCTTTCTAGCTCTCTGTGTTTGGATTTGTTTTGTTTTGTTCT
Figure 4. Nucleic acid sequence of the Apl II cDNA with its deduced amino acid sequence. Most of the sequence was determined from a 2.2-kb cDNA isolated from the randomly primed cDNA library. The 5 ' end of this sequence was cloned by anchored polymerase chain reaction (PCR; Frohman et al., 1988). At least four independent PCR-derived clones were sequenced for all coding regions, and three independent clones were sequenced in the $5^{\prime}$ untranslated region. Even though the next five codons can be read, the first methionine codon shown in the figure is probably not the initiator because it is a poor match to the consensus sequence (Kozak, 1981). The next methionine codon (square) has a proper consensus sequence, and the methionine residue it encodes aligns with the initiator of the rat $\mathrm{PKC}$ sequence.

\section{Biochemical properties of Apl I and Apl II PKCs}

To examine the biochemical properties of Apl I and Apl II, we obtained antisera that would recognize each isoform selectively.

Apl I. Because the C-terminus of Apl I is nearly identical to that of rat $\beta \mathrm{I}$ PKC (Fig. 2), this isoform was initially identified with an antisera to vertebrate $\beta$ I PKC (Ase et al., 1988). In later experiments, we used an antibody raised against a synthetic peptide with the C-terminal Apl I sequence. Both antibodies gave similar results. Western blot analysis reveals an $M_{r} 72,000$ protein in extracts of ganglia close to the predicted size of the enzyme inferred from the sequence of Apl I cDNA $\left(M_{r}, 74,000\right.$; Fig. $9 A$ ). Antisera to rat $\beta$ II PKC failed to react with any protein in the extracts nor did monoclonal antibodies to vertebrate $\alpha$-and $\gamma$-PKCs (Hidaka et al., 1988).

We tested the requirements for translocating Apl I protein both to natural and to artificial membranes to test whether the antigen recognized by the antisera has biochemical properties expected of a $\mathrm{Ca}^{2+}$-dependent PKC. The Apl I antigen is primarily cytosolic in extracts of neuronal tissue prepared with a 


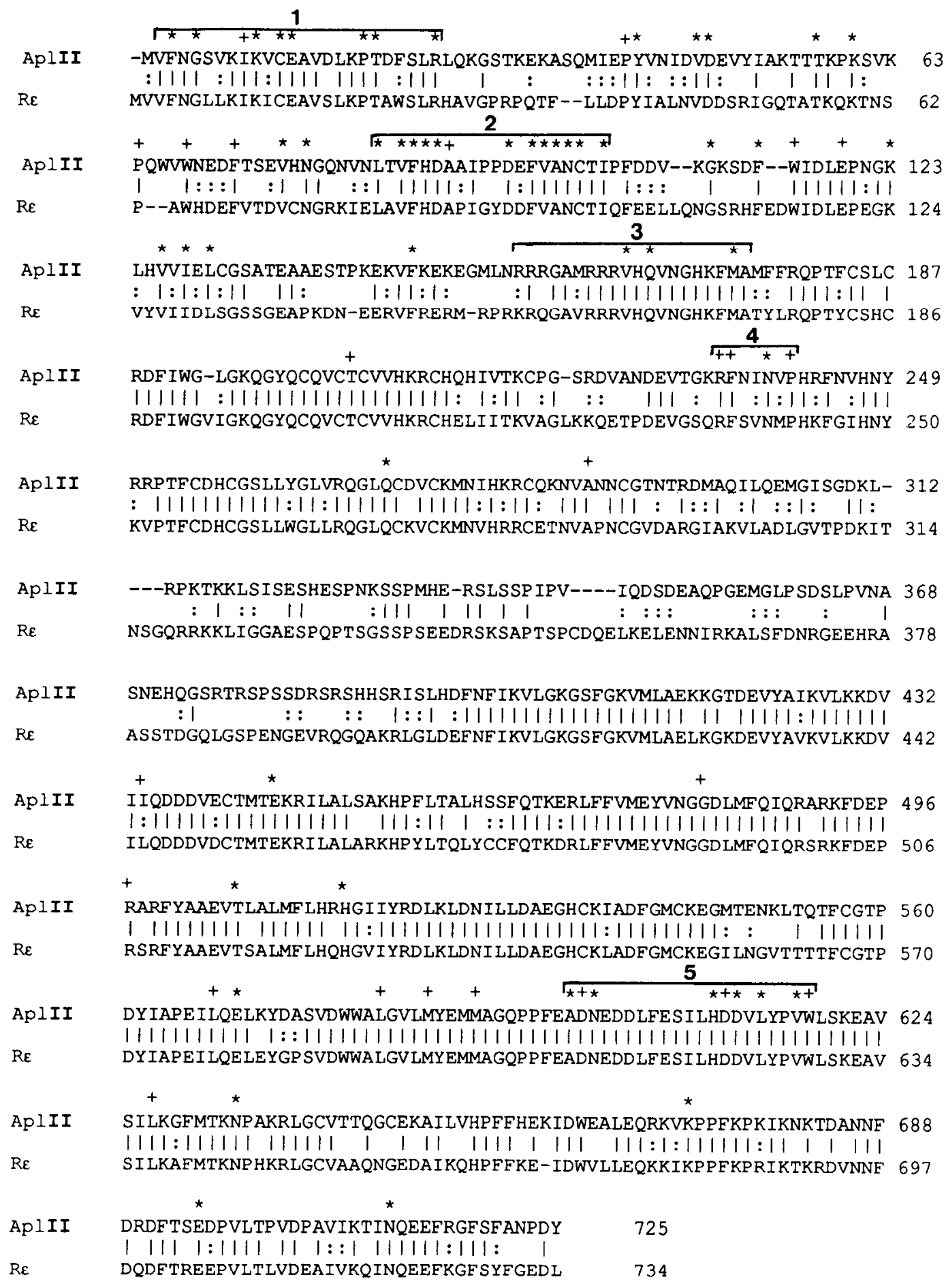

Figure 5. Comparison of Apl II with rabbit PKC $\epsilon$ (Ohno et al., 1988). Asterisks above the sequence are residues identical among rabbit PKC $\epsilon$, Drosophila 98F, and Apl II, but that are not in any other PKCs (mammalian $\alpha, \beta \mathrm{I}, \beta \mathrm{II}, \gamma, \delta, \zeta$, and Drosophila brain or eye-specific kinases). + indicates residues that are conserved in $\mathrm{Ca}^{2+}$-independent PKCs $(\delta$ or $\epsilon)$ but that are absent in $\mathrm{Ca}^{2+}$-dependent PKCs. The regions bracketed are discussed in the Results. Other symbols are as in Figure 3.

low concentration of $\mathrm{Ca}^{2+}\left(0.5 \mathrm{~mm}\right.$ EGTA) and $10 \mathrm{~mm} \mathrm{MgCl}_{2}$ (Fig. $9 \mathrm{~A}$; cf. 1 and 2 ). In the absence of $\mathrm{Ca}^{2+}$, phorbol ester added to the extract before the subcellular fractionation did not result in the translocation of the Apl I antigen to neuronal membranes (Fig. 9A, Table 1). This was surprising because it has previously been shown that PKC activity is translocated under these conditions (Table 1; Sacktor et al., 1988-1989). In contrast, we found that addition of phorbol ester does translocate the Apl I antigen to phosphatidylserine micelles (Fig. 9A, 3 and 4). This translocation appcars to require the presence of some $\mathrm{Ca}^{2+}$ ions, because the amount of kinase protein translocated is reduced in extracts prepared with $1 \mathrm{~mm}$ EGTA (data not shown).

In the absence of phorbol ester, the Apl I isoform is translocated to neuronal membranes by millimolar concentrations 


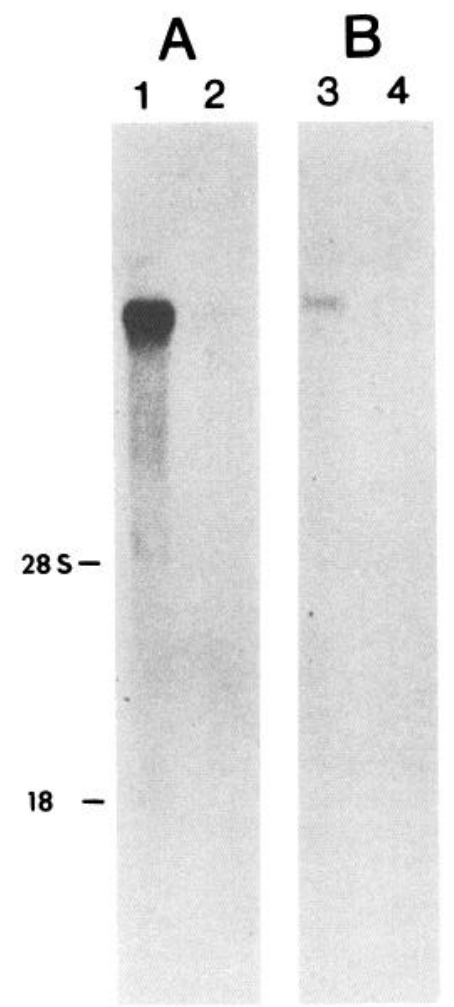

Figure 6. Northern blots of RNA from Aplysia nervous tissue with Apl I and Apl II cDNA probes. PolyA ${ }^{+}$RNA (lanes 1, 3) and total RNA (lanes 2,4$)$ isolated from nervous tissue $(10 \mu \mathrm{g}$ each) were electrophoresed and blotted onto nitrocellulose filters that were probed with Apl I $(A)$ or Apl II $(B)$ cDNA (see Fig. 1 for probes). Size is indicated by the location of rat 18 and $28 S$ ribosomal RNA.
Table 1. Isoform-specific translocation of PKC

\begin{tabular}{lccl} 
& \multicolumn{3}{l}{ Percent change on membrane } \\
\cline { 2 - 4 } Experiment & Apl I & Apl II & PKC activity \\
\hline PDBu & & & \\
$\quad$ Homogenates & $8 \pm 7(10)^{\mathrm{NS}}$ & $38 \pm 18(11)$ & $72 \pm 11(18)$ \\
$\quad$ Ganglia & $33 \pm 11(10)$ & $32 \pm 14(9)$ & $81 \pm 26(8)$ \\
5-HT $(20 \mu \mathrm{M})$ & $-9 \pm 8(8)^{\mathrm{Ns}}$ & $-5 \pm 6(8)^{\mathrm{Ns}}$ & $38 \pm 11(8)$ \\
$\quad$ Ganglia & $-9 \pm$
\end{tabular}

Values ( \pm SEs) are expressed as the mean percent difference of PKC on membranes between treated and contralateral control pleural-pedal ganglia determined either by Western blotting or by enzyme assay (Sacktor et al., 1988-1989; Sacktor and Schwartz, 1990). The number of independent determinations is given in parentheses. NS, not significantly different from 0 ( $p<0.05$, one-tailed $t$ test).

${ }^{a}$ In homogenates and for the activity measurements in intact ganglia, $200 \mathrm{~nm}$ PDBu was used; $1 \mu \mathrm{M}$ PDBu was used in the Western blotting experiments with intact ganglia because their connective tissue was not removed completely.

of $\mathrm{Ca}^{2+}$. At lower concentrations $(100-400 \mu \mathrm{M})$, the translocation is enhanced by phorbol ester (Fig. 9C). These results, which demonstrate that the antigen is a $\mathrm{Ca}^{2+}$-dependent $\mathrm{PKC}$, show that the translocation of Apl I to neuronal membranes by PDBu requires more $\mathrm{Ca}^{2+}$ than does its binding to phosphatidylserine micelles. The results also suggest that the isoform whose activity is translocated by PDBu at the lower concentrations of $\mathrm{Ca}^{2+}$ is not Apl I (Sacktor et al., 1988-1990; Table 1).

$\mathrm{Apl} \mathrm{II.} \mathrm{We} \mathrm{also} \mathrm{raised} \mathrm{antisera} \mathrm{to} \mathrm{a} \mathrm{synthetic} \mathrm{peptide} \mathrm{with} \mathrm{a}$ sequence from the C-terminus of Apl II that recognize an $M_{r}$, 87,000 protein (Fig. $9 B$ ), approximately the size expected from the cDNA clone $(84,000)$. In this Western blot, the protein appears as a wide band. It is likely that the protein undergoes posttranslational modification, because the band can be resolved into several discrete components (data not shown).
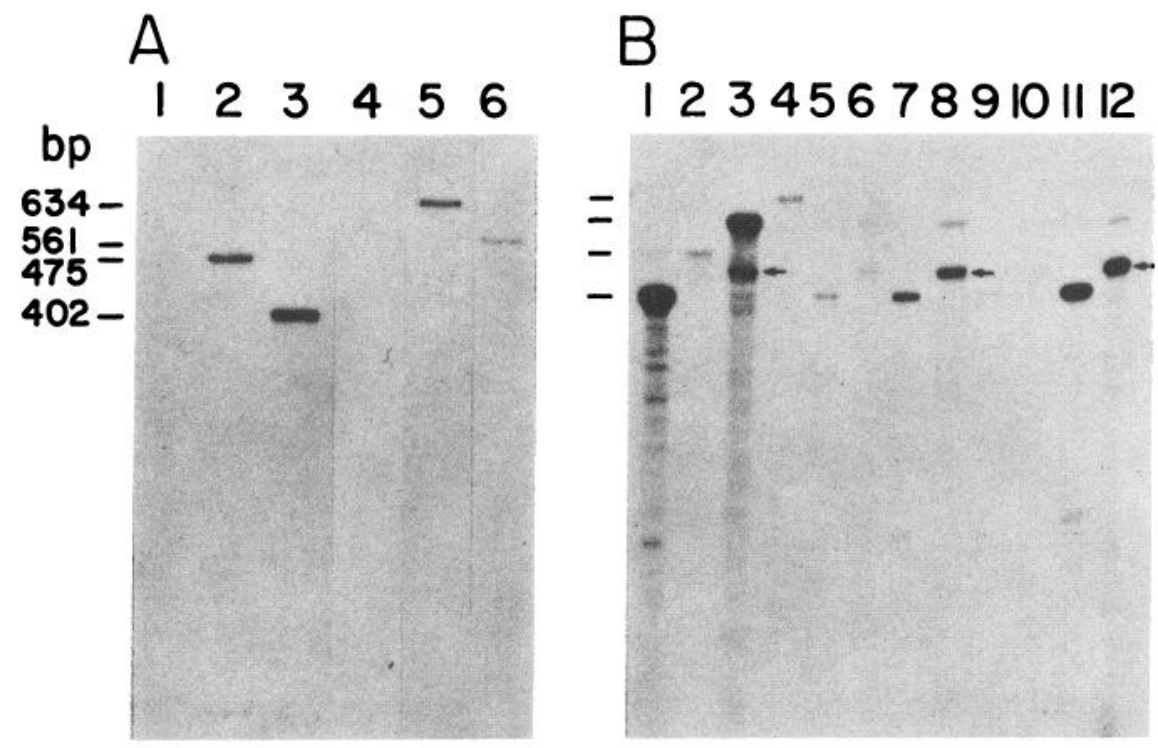

Figure 7. Sl nuclease protection experiments with Apl I and Apl II antisense RNA. A, Riboprobes were synthesized from the T3 primer of the cDNA clones described in Figure 1 that are subcloned in Bluescript phagemids. Lanes 2 and 5 show the Apl II and Apl I radiolabeled antisense RNA probes. These probes were completely digested by the nuclease (lanes 1 , 4). When mixed with $20 \mu \mathrm{g}$ of total nervous tissue RNA, fragments of 400 (lane 3) and 560 (lane 6) bp are protected. Densitometric scanning of the autoradiogram determined that Apl II RNA is three times more abundant than Apl I. The expected sizes (in bp) of protected and unprotected RNA fragments are indicated to the left. B. Expression of Apl I and Apl II RNA in Aplysia tissues. Total RNA $(20 \mu \mathrm{g}$ each) from nervous tissue (lanes 1,3$)$, buccal muscle $($ lanes 5,6$)$, gut $($ lanes 7,8$)$, salivary gland (lanes 9, 10), and ovotestis (lanes 11,12) was hybridized with radiolabeled Apl II or Apl I antisense RNA and treated with Sl nuclease. Lanes 2 and 4 are controls: Apl II and Apl I sense RNA hybridized to nervous tissue RNA and digested with the nuclease. The size of the RNA is indicated to the left of the figures. The arrows identify a suspected alternatively spliced form of the Apl I transcript. 

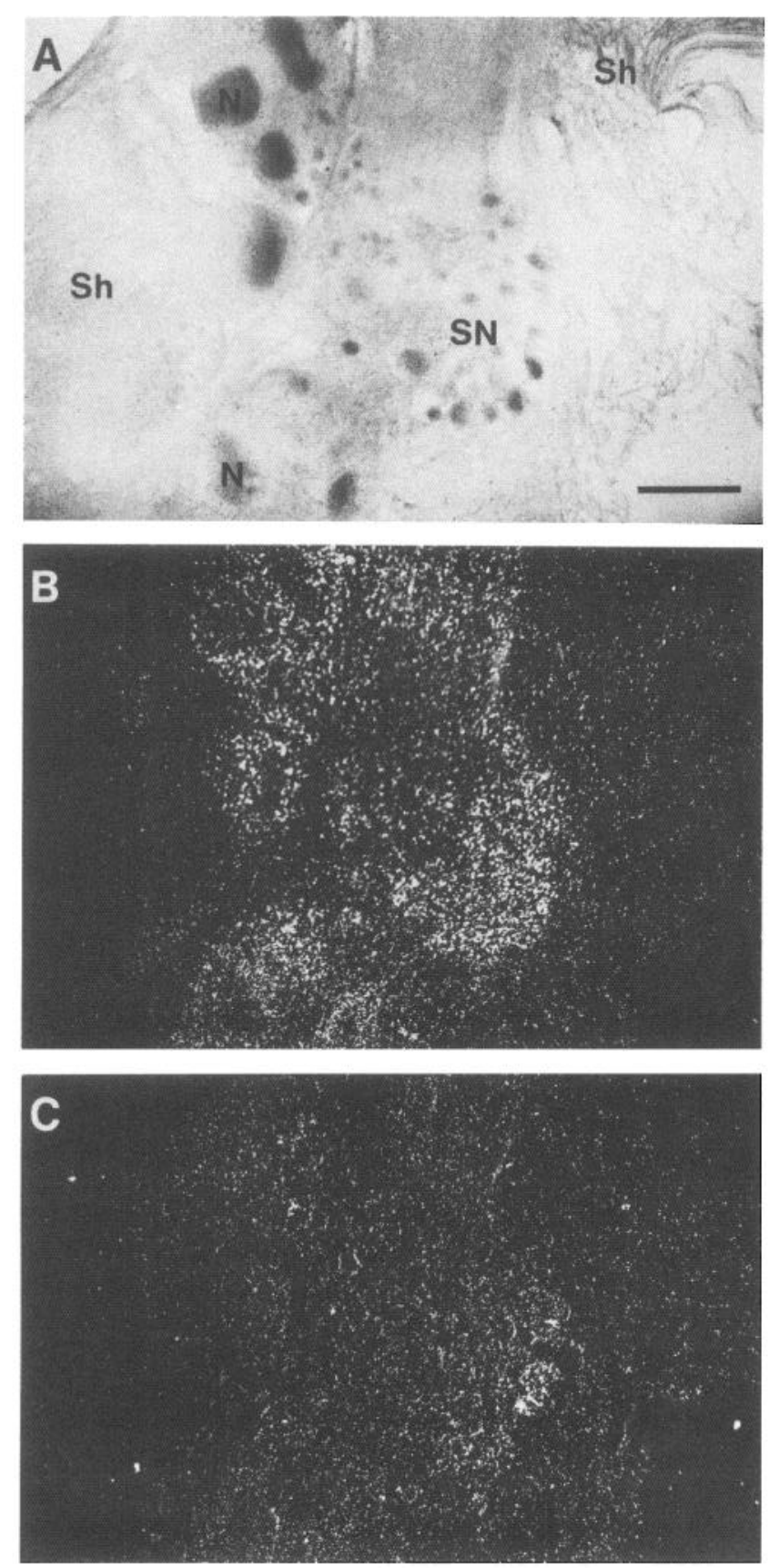

Figure 8. In situ hybridization with Apl II antisense RNA. A, Brightfield micrograph of a cryostat section $(16 \mu \mathrm{m})$ of the pleural ganglion: $S N$, the cluster of sensory neurons; $N$, unidentified neurons; $S h$, the connective tissue sheath of the ganglion. $B$, Dark-field micrograph of a section through the pleural ganglion hybridized to Apl II antisense RNA. Silver grains are seen over the sensory cells. $C$, Dark-field micrograph of an adjacent section hybridized to Apl II sense RNA (control). Scale bar, $100 \mu \mathrm{m}$.

The $M, 87,000$ protein recognized by Apl II antisera has the biochemical properties expected of a $\mathrm{Ca}^{2+}$-independent PKC. This isoform is translocated both to neuronal membranes and to phosphatidylserine micelles in the presence of phorbol ester (Fig. 9B, Table 1). Much more Apl II is translocated to phosphatidylserine micelles, however-as much as $90 \%$ in some experiments (data not shown). As expected from the absence of the $\mathrm{C} 2$ domain in this isoform, $\mathrm{Ca}^{2+}$ ion has no effect on the translocation of Apl II either to neuronal membranes or to phosphatidylserine micelles (Fig. 9B).

\section{Role of Apl I and Apl II in presynaptic facilitation}

Phorbol esters have been shown to potentiate synaptic transmission in Aplysia (Sawada et al., 1989; Taussig et al., 1989; Braha et al., 1990; Fossier et al., 1990). We found that treatment of isolated ganglia with PDBu results in significant translocation of both PKC isoforms as determined by Western blotting, but the translocation is less than that of PKC enzyme activity (Table 1).

Are the Apl I and Apl II isoforms of PKC translocated during presynaptic facilitation? Application of 5-HT, a transmitter that causes presynaptic facilitation in pleural-pedal ganglia, does not result in the translocation of either isoform (Table 1). This is surprising because sensitizing stimuli delivered to the intact animal and treatment of the isolated ganglia with 5-HT previously have been shown to cause translocation of PKC activity to membrane in sensory neurons and pleural-pedal ganglia (Sacktor and Schwartz, 1990; see also Table 1). These observations suggest that other isoforms of PKC are present in sensory cells, which are selectively translocated at low concentrations of $\mathrm{Ca}^{2+}$ by $\mathrm{PDBu}$ in homogenates and by $5-\mathrm{HT}$ in intact ganglia.

\section{Discussion}

Phylogeny of PKC

Some domains are highly conserved in PKCs, especially the catalytic region (C4) and the region that binds lipid activators (C1; Rosenthal et al., 1987; Schaeffer et al., 1989; Levin et al., 1990). Variable regions that differ among the $\mathrm{Ca}^{2+}$-dependent isoforms must be responsible for differences in the characteristic biochemical properties of these kinases. Because the variable (isoform-specific) regions are not conserved in invertebrates, it is difficult to predict the similarity of the biochemical properties of Apl I to those of the vertebrate major forms. Variable region V5, however, does show isoform-specific conservation throughout phylogeny (Fig. 3). Thus, antisera raised against V5 sequences in the vertebrate $\beta \mathrm{I}$ PKC cross-react with the Apl I protein. This C-terminal region is nearly identical in Apl I, Drosophila brain PKC, Drosophila 53E eye-specific PKC, and the vertebrate $\beta \mathrm{I}$ PKC. Furthermore, we have some indication that the splice site that results in the two mammalian transcripts, $\beta \mathrm{I}$ and $\beta \mathrm{II}$, is also conserved in Aplysia. V5 is likely to have similar functions in these PKCs.

In contrast, Apl II is similar to mammalian PKC $\epsilon$ and to the Drosophila $98 \mathrm{~F}$ kinase throughout the entire molecule, and can be considered a homolog of PKC $\epsilon$. A new member of the vertebrate $\mathrm{PKC}$ family (PKC $\eta$ ) expressed in skin and lung also contains most of these homologies (Osada et al., 1990). These enzymes should therefore have similar biochemical characteristics. Consistent with this hypothesis, Apl II does not phosphorylate histone well (W. S. Sossin and J. H. Schwartz, unpublished observations). Even though it is preferred for measuring $\mathrm{Ca}^{2+}$-dependent PKCs, histone is a poor substrate for the vertebrate $\epsilon$-enzyme (Schaap and Parker, 1990). V1 is a highly conserved isoform-specific region of unknown function in PKC $\epsilon$. We suggest that V1 may interact with an as yet unidentified cofactor in a way similar to that by which $\mathrm{Ca}^{2+}$-dependent PKCs are activated by $\mathrm{Ca}^{2+}$ ions through $\mathrm{C} 2$. It is reasonable to speculate that the $\mathrm{Ca}^{2+}$-independent PKCs also require a factor in addition to a lipid activator that increases their affinity for membrane in order to be enzymatically active. 

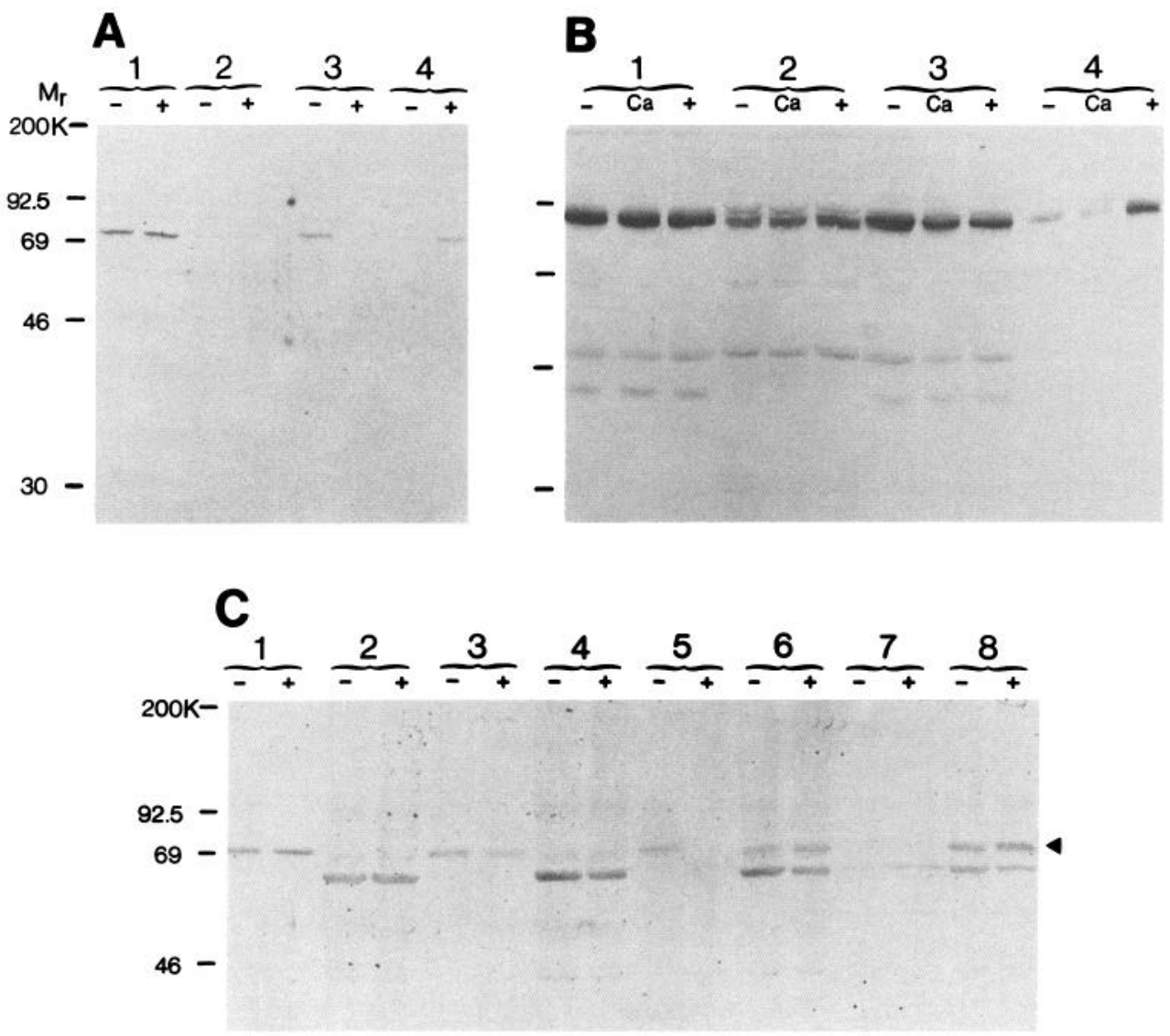

Figure 9. Effects of phorbol ester and $\mathrm{Ca}^{2+}$ ion on the subcellular distributions of Apl I and Apl II PKCs. A, Apl I: Western blots of supernatant $(1)$ and membrane (2) fractions of extracts of pleural-pedal ganglia $(20 \mu \mathrm{g}$ of protein per lane) incubated in the absence $(-)$ or presence $(+)$ of 200 $\mathrm{nM}$ PDBu. The supernatant fraction was incubated with $150 \mu \mathrm{g} / \mathrm{ml}$ phosphatidylserine without (-) or with (+) $200 \mathrm{~nm}$ PDBu and centrifuged again to give a supernatant (3) and a membrane (4) fraction. The rat anti- $\beta$ I PKC antiserum reacts with an $M, 76,000$ protein in the original supernatant. This protein is not translocated to neuronal membranes in the presence of PDBu, but is translocated to phosphatidylserine micelles. $B$, Apl II: Supernatant $(1)$ and membrane (2) fractions incubated in the absence $(-)$ or presence $(+)$ of $200 \mathrm{nM}$ PDBu, or in the presence of $400 \mu \mathrm{M}$ Ca $(C a$; $20 \mu \mathrm{g}$ of protein per lane). The supernatant fraction was then incubated with $150 \mu \mathrm{g} / \mathrm{ml}$ phosphatidylserine without $(-)$ or with $(+) 200 \mathrm{nM}$ PDBu, or in the presence of $400 \mu \mathrm{M} \mathrm{Ca}^{2+}(C a)$, and centrifuged again to obtain supernatant (3) and membrane (4) fractions. $C$, Synergistic effect of $\mathrm{Ca}^{2+}$ and PDBu on translocation of Apl I. Western blot of supernatant $(1,3,5$, and $7 ; 15 \mu \mathrm{g})$ and membrane fractions $(2,4,6$, and $8 ; 20 \mu \mathrm{g})$ after incubation in $\mathrm{Ca}^{2+}$ buffers without (-) or with (+) $200 \mathrm{nM}$ PDBu. $\mathrm{Ca}^{2+}$-ion concentrations are $0(0.5$ EGTA) $(1,2), 120 \mu \mathrm{M}(3,4), 450 \mu \mathrm{M}(5,6)$, and $1 \mathrm{~mm}(7,8)$. As in $A, \mathrm{Apl} \mathrm{I}$ is not translocated to membranes in the absence of $\mathrm{Ca}^{2+}$. Incubation with $120 \mu \mathrm{M} \mathrm{Ca}{ }^{2+}$ reduces the amount of Apl I in the cytoplasm, and the translocation is enhanced by PDBu. In the absence of PDBu, approximately half of the Apl I PKC is translocated in the presence of $450 \mu \mathrm{M} \mathrm{Ca}{ }^{2+}$. All of it is translocated in the presence of PDBu. Apl I is completely translocated in the presence of 1 mM Ca ${ }^{2+}$ even without PDBu. The arrowhead points to the Apl I antigen. This experiment was repeated three times with similar results. Size is indicated by the migration of protein markers shown to the left.

\section{Biochemical characterization of the two Aplysia isoforms}

The proteins recognized by antisera for Apl I and Apl II have many of the biochemical properties expected from the sequence similarities to vertebrate enzymes. Apl I can be translocated to membranes by $\mathrm{Ca}^{2+}$, and the translocation is enhanced by phorbol ester. The Apl II isoform is not translocated by $\mathrm{Ca}^{2+}$, but can be translocated by phorbol ester.

There are two biochemical questions that arise from the translocation experiments. First, why are Apl I and Apl II translocated to such a limited extent to neuronal membranes by phorbol ester (Table 1)? In experiments with membranes from other tissues, PKCs have been found to be almost quantitatively translocated by phorbol ester (Kraft and Anderson, 1983; Akita et al., 1990; Godson et al., 1990; Kiley et al., 1990). This difference could be explained if the Aplysia membranes are deficient in binding sites for the kinase. We found almost total translocation of PKC to phosphatidylserine micelles. Neuronal membranes may therefore lack available phosphatidylserine. Perhaps there are phosphatidylserine-binding proteins in neurons that regulate PKC activity.

The second biochemical question is why phorbol ester causes Apl I to be translocated in homogenates lacking $\mathrm{Ca}^{2+}$, but not in intact ganglia (Table 1). How do intact ganglia differ from homogenates? One difference may be higher resting concentrations of $\mathrm{Ca}^{2+}$ in intact cells than in homogenates prepared with $0.5 \mathrm{~mm}$ EGTA. Another difference may be that Apl I is positioned in cells to facilitate translocation, but that homogenization disrupts this organization.

\section{The role of Apl I and Apl II in synaptic plasticity}

PKC activity is translocated to membranes in intact pleuralpedal ganglia exposed to 5-HT and is translocated to membranes in homogenates by phorbol ester (Sacktor et al., 1988-1989; 
Sacktor and Schwartz, 1990). It should be pointed out that these measurements, which used histone III-S as substrate, underrepresented any contribution from the $\mathrm{Ca}^{2+}$-independent PKCs. Although the translocation of kinase activity observed in these experiments without significant translocation of Apl I and Apl II (Table 1) can be explained in several ways, a likely explanation is that the translocated activity consists of isoforms of PKC other than Apl I and Apl II. We cannot rule out the possibility that the observed translocation of kinase activity results from the activation of enzyme already associated with the membrane, however, because this would not be detected on Western blots. Nevertheless, this is unlikely because cytosolic PKC decreased in the experiments of Sacktor and Schwartz (1990).

Phorbol esters potentiate synaptic transmission in Aplysia. Apl I and Apl II are translocated by phorbol ester in intact ganglia (Table 1) and could participate in the potentiation observed in the electrophysiological experiments. It is important to note that there are differences between the pharmacological effect of phorbol esters, which can activate all isoforms of PKC, and neurotransmitters such as 5-HT, which appear to activate specific isoforms selectively.

We found that Apl I needs elevated concentrations of $\mathrm{Ca}^{2+}$ to be translocated. Recently, 5-HT has been shown not to cause increased $\mathrm{Ca}^{2+}$ influx in sensory cells, though influx of $\mathrm{Ca}^{2+}$ is enhanced by exposure to 5-HT if the cell is depolarized (Blumenfeld et al., 1990). Apl I therefore may require both 5-HT and depolarization to be active, while other isoforms of PKC could be active at resting concentrations of $\mathrm{Ca}^{2+}$. Coupling of $\mathrm{Ca}^{2+}$ influx and treatment with 5-HT are also the conditions postulated for activity-dependent presynaptic facilitation (Abrams and Kandel, 1988).

Subtle changes in intracellular $\mathrm{Ca}^{2+}$, availability of lipids, and, possibly, protein phosphorylation or the presence of PKC-binding proteins could have profound effects on the translocation and activation of PKC. These regulatory mechanisms differentially operating on the several kinase isoforms might be needed to produce a great variety of actions in the neuron. Further dissection of the biochemical anatomy of the PKCs activated during specific physiological events is necessary for understanding the molecular mechanisms underlying synaptic modulation.

\section{References}

Abrams TW, Kandel ER (1988) Is contiguity detection in classical conditioning a system or a cellular property? Learning in Aplysia suggests a possible molecular site. Trends Neurosci 11:128-135.

Akers RF, Lovinger DM, Colley PA, Linden DJ, Routtenberg A (1986) Translocation of protein kinase $\mathrm{C}$ may mediate hippocampal longterm potentiation. Science 231:587-589.

Akita Y, Ohno S, Konno Y, Yano A, Suzuki K (1990) Expression and properties of two distinct classes of the phorbol ester receptor family, four conventional protein kinase $\mathrm{C}$ types and a novel protein kinase C. J Biol Chem 285:354-362.

Alkon DL, Naito S, Kubota MN (1988) Regulation of Hermissenda $\mathrm{K}^{+}$channels by cytoplasmic and membrane-associated C-kinase. J Neurochem 51:903-917.

Ase K, Saito N, Shearman MS, Kikkowa U, Ono Y (1988) Different cellular expression of $\beta \mathrm{I}-$ and $\beta \mathrm{II}$ subspecies of protein kinase $\mathrm{C}$ in rat cerebellum. J Neurosci 8:3850-3856.

Bergold PJ, Sweatt JD, Winicov I, Weiss KR, Kandel ER, Schwartz JH (1990) Protein synthesized during long-term facilitation is needed for the persistent loss of regulatory subunits of the Aplysia cAMPdependent protein kinase. Proc Natl Acad Sci USA 87:3788-3791.

Beushausen S, Bergold P, Sturner S, Elste A, Roytenberg V, Schwartz JH, Bayley H (1988) Two catalytic subunits of cAMP-dependent protein kinase generated by alternative RNA splicing are expressed in Aplysia neurons. Neuron 1:853-864.
Blumenfeld H, Spira ME, Kandel ER, Siegelbaum SA (1990) Facilitatory and inhibitory transmitters modulate calcium influx during action potentials in Aplysia sensory neurons. Neuron 5:487-499.

Braha O, Dale N, Hochner B, Klein M, Abrams TW, Kandel ER (1990) Second messengers involved in the two processes of presynaptic facilitation that contribute to sensitization and dishabituation in Aplysia sensory neurons. Proc Natl Acad Sci USA 87:2040-2044.

Burns DJ, Bloomenthal J, Lee M-H, Bell R (1990) Expression of the $\alpha, \beta \mathrm{II}$, and $\gamma$ protein kinase $\mathrm{C}$ isozymes in the baculovirus-insect cell expression system. J Biol Chem 265:12044-12051.

Conn PJ, Strong JA, Azhderian EM, Nairn AC, Greengard P, Kaczmarek LK (1989) Protein kinase inhibitors selectively block phorbol ester- or forskolin-induced changes in excitability of Aplysia neurons. J Neurosci 9:473-479.

Coussens L, Rhee L, Parker PJ, Ullrich A (1987) Alternative splicing increases the diversity of the human protein kinase $C$ family. DNA 6:389-394.

Devereaux J, Haeberli P, Smithies O (1984) A comprehensive set of sequence analysis programs for the VAX. Nucleic Acids Res 12:387395.

Eliot LS, Dudai Y, Kandel ER, Abrams TW (1989) $\mathrm{Ca}^{2+}$-calmodulin sensitivity may be common to all forms of neuronal adenylate cyclase. Proc Natl Acad Sci USA 86:9564-9568.

Farley J, Auerbach S (1986) Protein kinase $C$ activation induces conductance changes in Hermissenda photoreceptors like those seen in associative learning. Nature 319:320-322.

Fossier P, Baux G, Tauc L (1990) Activation of protein kinase C by presynaptic FLRFamide receptors facilitates transmitter release at an Aplysia cholinergic synapse. Neuron 5:479-486.

Frohman MA, Dush MK, Martin GR (1988) Rapid production of full-length cDNAs from rare transcripts: amplification using a single gene-specific oligonucleotide primer. Proc Natl Acad Sci USA 85: 8998-9002.

Gingrich KJ, Byrne JH (1985) Simulation of synaptic depression, posttetanic potentiation, and presynaptic facilitation of synaptic potentials from sensory neurons mediating the gill-withdrawal reflex in Aplysia. J Neurophysiol 53:652-669.

Godson C, Weiss BA, Insel PA (1990) Differential activation of protein kinase $\mathrm{C} \alpha$ is associated with arachidonic release in Madin-Darby canine kidney cells. J Biol Chem 265:8369-8372.

Hidaka $H$, Tanaka $T$, Onoda $K$, Hagiwara $M$, Watanabe $M$, Ohta $H$, Ito $Y$, Tsurudome M, Yoshida T (1988) Cell type-specific expression of protein kinase $\mathrm{C}$ isozymes in the rabbit cerebellum. J Biol Chem 263:4523-4526.

Hochner B, Klein M, Schacher S, Kandel ER (1986) Additional components in the cellular mechanism of presynaptic facilitation contributes to behavioral dishabituation in Aplysia. Proc Natl Acad Sci USA 83:8794-8798.

Housey GM, O'Brien CA, Johnson MD, Kirschmeier P, Weinstein IB (1987) Isolation of $\mathrm{CDNA}$ clones encoding protein kinase C: evidence for a protein kinase C-related gene family. Proc Natl Acad Sci USA 84:1065-1069.

Huang K-P, Huang FL (1990) Differential sensitivity of protein kinase $\mathrm{C}$ isozymes to phospholipid induced activation. J Biol Chem 265: 738-744.

Huang KP, Huang FL, Nakabayashi H, Yoshida Y (1989) Biochemical characterization of rat brain protein kinase $\mathrm{C}$ isozymes. J Biol Chem 263:14839-14845.

Kaczmarek L (1987) The role of protein kinase $C$ in the regulation of ion channels and neurotransmitter release. Trends Neurosci 10:3033.

Kaibuchi K, Fukomoto Y, Oku N, Takai Y, Arai K, Muramatsu M (1989) Molecular genetic analysis of the regulatory and catalytic domains of protein kinase C. J Biol Chem 264:13489-13496.

Kikkawa U, Ogita K, Ono Y, Asaoka Y, Shearman MS, Fujii T, Ase K, Sekiguchi K, Igarashi K, Nishizuka Y (1987) The common structure and activities of four subspecies of rat brain protein kinase $\mathrm{C}$ family. FEBS Lett 223:212-216.

Kiley S, Schaap D, Parker P, Hsieh L-L, Jaken S (1990) Protein kinase $\mathrm{C}$ heterogeneity in $\mathrm{GH} 4 \mathrm{Cl}$ rat pituitary cells. J Biol Chem 265:1570415712.

Kozak M (1981) Possible role of flanking nucleotides in recognition of the AUG initiator codon by eukaryotic ribosomes. Nucleic Acids Res 9:5233-5252.

Kraft AS, Anderson WB (1983) Phorbol esters increase the amount 
of $\mathrm{Ca}^{2+}$ phospholipid dependent protein kinase associated with the membrane. Nature 301:521-523.

Laemmli UK (1970) Cleavage of structural proteins during the assembly of the head of bacteriophage T4. Nature 227:680-685.

Levin DE, Fields FO, Kunisawa R, Bishop JM, Thorner J (1990) A candidate protein kinase $\mathrm{C}$ gene, $\mathrm{PKCl}$, is required for $S$. cerivisiae cell cycle. Cell 62:213-224.

Malinow R, Madison DV, Tsien RW (1988) Persistent protein kinase activity underlying long-term potentiation. Nature 335:820-824.

Nishizuka Y (1988) The molecular heterogeneity of protein kinase C and its implications for cellular regulation. Nature 334:661-665.

Ohno S, Akita Y, Konno Y, Imajoh S, Suzuki K (1988) A novel phorbol ester receptor/protein kinase, $\mathrm{nPKC}$, distantly related to the protein kinase $C$ family. Cell 53:731-741.

Olds JL, Anderson ML, McPhig DL, Staten LD, Alkon DL (1989) Imaging of memory-specific changes in the distribution of protein kinase $C$ in the hippocampus. Science 245:866-869.

Ono Y, Fujii T, Ogita K, Kikkawa U, Igarashi K, Nishizuka Y (1988) The structure, expression, and properties of additional members of the protein kinase C family. J Biol Chem 263:6927-6932.

Osada S, Mizuno K, Saido T, Akita Y, Suzuki K, Kuroki T, Ohno S (1990) A phorbol ester receptor/protein kinase nPKC $\eta$, a new member of the protein kinase $C$ family, predominantly expressed in lung and skin. J Biol Chem 265:22434-22440.

Parker PJ, Coussens L, Totty N, Rhee L, Young S, Chen E, Stabel S, Waterfield MD, Ullrich A (1986) The complete primary structure of protein kinase $\mathrm{C}$-the major phorbol ester receptor. Science 233 : 853-859.

Rane SG, Walsh MP, McDonald JP, Dunlap K (1989) Specific inhibitors of protein kinase $\mathrm{C}$ block transmitter-induced modulation of sensory neuron calcium current. Neuron 3:239-245.

Rosenthal A, Rhee L, Yadegari R, Paro R, Ullrich A, Goeddel DV
(1987) Structure and nucleotide sequence of Drosophila melanogastor protein kinase $\mathrm{C}$ gene. EMBO J 6:433-441.

Sacktor TC, Schwartz JH (1990) Sensitizing stimuli cause translocation of protein kinase $\mathrm{C}$ in Aplysia sensory neurons. Proc Natl Acad Sci USA 87:2036-2039.

Sacktor TC, Kruger KE, Schwartz JH (1988-1989) Activation of protein kinase $\mathrm{C}$ by serotonin: biochemical evidence that it participates in the mechanisms underlying facilitation in Aplysia. J Physiol (Paris) $83: 45-52$

Sanger F, Nicklen S, Coulson AR (1977) DNA sequencing with chainterminating inhibitors. Proc Natl Acad Sci USA 74:5463-5467.

Sawada M, Cleary LJ, Byrne JH (1989) Inositol triphosphate and activators of protein kinase $\mathrm{C}$ modulate membrane currents in tail motor neurons of Aplysia. J Neurophysiol 61:302-310.

Schaap D, Parker PJ (1990) Expression, purification, and characterization of protein kinase C- $\epsilon$. J Biol Chem 265:7301-7307.

Schaeffer E, Smith D, Mardon G, Quinn W, Zuker C. (1989) Isolation and characterization of two new protein kinase $C$ genes, including one specifically expressed in photoreceptor cells. Cell 57:403-412.

Schwartz JH, Elste $\Lambda$, Shapiro E, Gotoh H (1986) Biochemical and morphological correlates of transmitter type in $\mathrm{C} 2$ an identified histaminergic neuron in Aplysia. J Comp Neurol 245:401-421.

Sekiguchi K, Tsukudawa M, Ogita K, Kikkawa U, Nishizuka Y (1987) Three distinct forms of rat brain protein kinase C: differential response to unsaturated fatty acids. Biochem Biophys Res Commun 145:797802.

Strong JA, Fox AP, Tsien RW, Kaczmarek LK (1987) Stimulation of protein kinase $\mathrm{C}$ recruits covert calcium channels in Aplysia bag cell neurons. Nature 325:714-717.

Taussig R, Sweet-Cordero A, Scheller RH (1989) Modulation of ionic currents in Aplysia motor neuron B15 by serotonin, neuropeptides, and second messengers. J Neurosci 9:3218-3229. 